\title{
ON THE QUESTION OF INCLUSION
}

\author{
David Montejano
}

se approach the end of the twentieth century, the national media
has begun to issue the inevitable, introspective analyses of Ameri-
can politics and society. In light of a number of prominent racialized events - the Los Angeles riots of 1992, the anti-immigrant campaigns of 1994-1995, the O.J. Simpson trial of the same years, the Million Man March of 1995 , the anti-affirmative action initiatives of $1995-1997$, to name just a few - the dominant tone of these media analyses has been a somber and anxious one. It reflects the anxiety of a nation obsessed with race, as one noted sociologist put it: "we think race, act race, march race, tabulate race, celebrate race, fear race." The prophecy of W. E. B. Du Bois, made in 1903, that the problem of the twentieth century would be that of the "color line," may hold up well for another century. On the eve of the twenty-first century, the most active fault lines in U.S. society remain race and ethnic divisions. ${ }^{1}$

Not surprisingly, many of these national commentaries, noting the rapid increase in the U.S. Latino population, have elaborated a common theme around the notion of the "browning of America." Two disturbing lines of reasoning have characterized much of the public discussion. On the one hand, some journalists and politicians talk in alarming tones about the possibility of an "ethnic disintegration" of American society. An April 1990 issue of Time put the matter bluntly: "What will the U.S. be like when whites are no longer the majority?" ${ }^{2}$ Whose history, values, language, and identity will count? One commentator in the conservative National Interest warned his audience that the Latino "value system" has been "the principal obstacle to human progress throughout Hispanic America." Latino barrios, by reinforcing these values, thus pose a special danger: "Poor enclave communities not only make it 
easier for homeland values and language to persist, but they also possess the potential, particularly during bad economic times, for resentment-driven violence, such as the rioting in the Mount Pleasant district of Washington, D.C. in the spring of 1991 or the devastating April-May 1992 Los Angeles riots. One-third of those apprehended in Los Angeles for looting were illegal Hispanic immigrants." ${ }^{3}$

Such anxiety about Latinos is evident among liberal commentators as well. In the 1990s, the moderate magazine Atlantic Monthly has treated its readers to several ominous special reports on the U.S.-Mexican border, concluding in 1992 that "no one knows the consequences of Mexican immigration: it is a movement of the largest scale, immensely complicated, around which various arguments can easily be constructed ... [but] these newcomers may indeed be the ones we cannot accommodate." One 1996 article, penned by Stanford historian David Kennedy, starkly warns of "the reconquista," of the possibility "that in the next generation or so we will see a kind of Chicano Quebec take shape in the American Southwest." 4 In short, conservatives and liberals alike have created a melodramatic, public discourse about threats to America from a growing Latino presence.

The second line of reasoning in this national discussion displays a righteous anger about the political "activism" of the U.S.-Mexican population. Nationally syndicated columnist Georgie Ann Geyer, for example, took a swipe in December 1992 at the "Hispanic advocacy movement," organizations that have consistently pushed for increased immigration, bilingual education, Spanish-language ballots, and "other such issues," by gushing about a "really surprising" poll of Hispanic Americans. The survey showed that Latinos actively want to reduce immigration, that they believe people living in this country should speak English, and that "the diverse and patriotic real Hispanic American community wants to adhere to the broader interests of the common good and of responsible Americanism rather than to the interests of professional spokespersons." Geyer, who in the 1980 os believed that the Southwest was on the verge of becoming another "Lebanon," was plainly relieved by this finding - that Latinos are not so different, after all. ${ }^{5}$

Such reasoning - that Latinos are "not so different" - has led several conservative analysts to argue that Hispanics are guilty of "opportunism" - of abusing racial entitlements and preferences intended exclusively for African Americans. Political scientist Peter Skerry, for example, has argued that Mexican Americans are essentially immigrants who define themselves as a minority group only because their self-interested political leadership has been "seduced" by affirmative action "remedies" such as the Voting Rights Act. According to Skerry, Hispanics simply have no claim to such policies and remedies: "Whatever the merits of affirmative action for black Americans, it makes little sense 
to extend its benefits to those whose claims on the nation's conscience are far less cogent - and who come here expecting no special help." Skerry concludes that if we do not withdraw benefits from Hispanics, "we acquiesce in the rewriting of the social compact this nation has had with immigrants since its founding." Ironically, Skerry does a considerable amount of rewriting of history and politics to carry out his polemical argument. In Skerry's treatment, the United States has no history of nation building worth exploring. Rather, the nation is assumed to have had a fixed space in which non-English speakers have been by definition immigrants.

Regardless of which line of reasoning is pursued, whether warning of ethnic disintegration or opportunism, these worrisome commentaries generally attempt no serious historical grounding. Skerry and others are free to portray Mexican and Asian Americans as "new" or "undeserving minorities" locked in a battle with African Americans for limited government resources. Or, as a rather naive article in the New York Times Magazine put it, "the new minorities' affirmative-action claims for fairness can't help but come at the expense of blacks." The provocative, divisive nature of this neoconservative argument is hardly concealed. With the rise of racial tensions, even liberals take up the argument.

In a troubling Atlantic Monthly assessment of the 1992 Los Angeles riot, for example, Jack Miles warns of an emerging struggle between Latinos and Blacks "for the bottom rung." Because white employers fear or disdain blacks and trust Latinos, Miles argues, there is widespread preferential hiring of Latinos for menial jobs - "the largest affirmative-action program in the nation, and one paid for, in effect, by blacks." But, reasons Miles, if the Mexican border were sealed off, a desperately needed safety valve for Mexico would be eliminated, and this "could foster the rise in that country of a terrorist movement like Peru's Shining Path." 8 The horns of Miles's dilemma now become clear: regardless of which minority wins the battle for the "bottom rung," violence will probably result. Not once in his pessimistic analysis does Miles question his base assumption that the "bottom rung" should be a preserve for African or Mexican Americans.

Without much exaggeration, one could say that such unabashed speculation in the national media and academia displays symptoms of manic depression. Bouts of hysteria may be followed by reassurances or resignation, only to have the cycle repeat itself, sometimes within the same commentary. The delusion of the analysts lies in their unspoken belief that the race question refers to "those people"-Mexicans, Blacks, Asians - while they, naturally, speak for the "national" interest. Speaking for the "nation" disguises the "whiteness"the race consciousness - of their perspective: their words are presumed to be part not of a racialized discourse but of an objective, transcendent American 
discourse. And so they speak "for the common good," composing a "national" discourse that manifests a profound ignorance and fear of Latinos and Blacks. Jack Miles's "browns vs. blacks" analysis, for example, was based on his long familiarity with the Mexican family that worked as domestics in the Miles residence. Out of such whimsical, anecdotal material have come alarming arguments with severe political implications.

These much publicized reactions and perspectives on the "browning of America" form the stark backdrop for the following collection of case studies. Needless to say, the general perspective of these studies is thoroughly different from that of the national print media I have just reviewed. The focus of the following essays is not on disintegration but on inclusion, not on opportunism but on activism to secure respect and equality.

By "inclusion" I refer to a basic recognition of Mexican Americans as a legitimate U.S. citizenry. Inclusion refers, in the most specific sense, to the extension and exercise of first-class citizenship. At the most general, it may refer to a broadening of the political culture and meanings associated with "Americanness." Defined generally in this manner, each of the following studies explores some aspect of inclusion; this is the common thread that makes the volume a collective whole.

The ten original contributions in this volume all take their departure point with the "Chicano movement," an integral part of the U.S. civil rights movement of the sixties and seventies. The concern in most of the case studies is to understand the type of "institutionalization" or "accommodation" that has characterized Chicano politics since the mid seventies. They describe various efforts to secure political influence and the contradictory results apparently achieved. In a sense, these studies represent a collective assessment of "postmovement" politics in the Mexican American community. What was achieved? What was lost? Where are we headed?

In answering such questions, the following studies provide a suggestive review of events and tendencies from the mid seventies through the early nineties. Rodolfo Rosales looks at San Antonio politics and the young Mayor Henry Cisneros to understand the unexpected consequences of single-member districts, at the time regarded as an important civil rights victory. Teresa Córdova, in her study of Chicago politics, describes the rise and fall of a progressive Black-Latino coalition under the brief tenure of Mayor Harold Washington. Mary Pardo's description of the "Mothers of East Los Angeles," a church-based community organization, outlines the manner in which activism and citizenship is "gendered." The bittersweet results of the creation of a state agricultural labor-relations agency, a goal long sought by California farmworkers, are analyzed in Margarita Decierdo's article. Phillip Gonzales's account of affirmative action politics at the University of New Mexico suggests the limits of 
"ethnic advocacy" as one moves up the institutional ladder. Both Christine Sierra and Antonio González, through their respective studies of immigration reform and Central American policy, provide insights into the unprecedented way in which "Hispanic" concerns and pressures have begun to influence national policy making. Eric Xavier suggests the problematic making of an American dream in the artistic and political evolution of Luis Valdez's work from farmworker theater to Hollywood production. And Martín Sánchez Jankowski, using survey data from three major cities, documents similar ambitions and dilemmas in the attitudes of former nationalists. Finally, in order to demonstrate that "inclusion" is a contingent and reversible circumstance, I use the forecasts of demographers and economists to outline a possible exclusionary future for Anglo-Mexican relations.

Together these studies suggest the increasing breadth and complexity of Chicano politics and society in the late twentieth century. Geographically the volume points to the importance of "Hispanic" politics in the Southwest as well as in Chicago wards and in the congressional halls of Washington, D.C., with ramifications in Mexico and Central America. The volume discusses "nontraditional" politics stemming from gender identity, environmental issues, theater production, labor organizing, and university policy making, along with the more traditional politics revolving around state and city government, the Congressional Hispanic Caucus, and various advocacy organizations.

What gives these various studies a sense of unity, as noted before, is the question of inclusion. In spite of different approaches and interests, the following studies clearly demonstrate that whatever political inclusion has taken place, it has been a partial one, uneven and full of contradictions. They suggest as well that inclusion be seen not as a permanent circumstance but rather as a contingent and negotiable one.

How can one speak of "inclusion" in light of the current backlash against immigrants, civil rights, voting rights, affirmative action, bilingual education? This question of inclusion draws its meaning from a historical as well as a present-day context. In other words, in order to understand this orientation, some basic background in history is necessary; then the individual studies can be properly introduced.

\section{A HISTORY OF NATION BUILDING}

The notion of inclusion suggests that we have witnessed a qualitative transformation of race relations from some pattern or history of exclusion and control. In the case of the Chicano or Mexican American experience, any historical assessment must recognize its nineteenth-century origins in the Mexican War and the annexation of the northern half of Mexico. It must deal candidly 
with the sentiments and structures of exclusion that were triggered by conflict and war. The fear about "Mexicanization" or "Latinization" can be traced back to such roots, as exemplified by a warning given at the 1845 Texas Constitutional Convention about allowing Mexicans the right to vote: "Silently they will come moving in; they will come back in thousands ... and what will be the consequence? Ten, twenty, thirty, forty, fifty thousand may come in here, and vanquish you at the ballot box though you are invincible in arms. This is no idle dream; no bugbear; it is the truth." 9 More than a century and a half later, such sentiment still strikes a responsive chord in the American imagination.

What is important to note is the sharp reorientation that a frank nineteenth-century history introduces. Most pundits and scholars who comment on the worrisome immigration situation assume that the nation has had preformed, fixed boundaries into which poured immigrants who eventually melted into an American stock. There is no examination of the nationbuilding experience itself, a national experience that involved Indian wars, plantation slavery, wars with Mexico and Spain, and expansion to California and eventually to Puerto Rico, Hawaii, and the Philippines. Such failures of historical memory are critical, for only in this way can one ignore the manner in which nation building and conquests of "people of color"- reds, blacks, browns, and yellows - have fused race consciousness ("whiteness") and national identity ("Americanness") and profoundly shaped national politics. ${ }^{10}$

Immigration, of course, was and is a basic element of the American experience, but twentieth-century immigrants stepped into a world shaped by a past. The massive waves of European and Mexican immigrants of this century assimilated the cultural lore and political lessons of the nineteenth century, even as they put in place a contemporary modern economy. Assimilation occurred, but along ethnic-racial lines. Thus, for most of the twentieth-century Southwest, "American" generally meant "white," an identity that melted various European groups (German, Irish, Polish, Italian, Jewish) into one, while "Mexican" likewise referred to race and not to citizenship.

In short, the Mexican in the twentieth-century United States was seen as "another" race problem and handled in much the same way as the African American was, through segregationist policies and institutions. Indeed, in spite of their very different experiences in the nineteenth century, the parallels between African American and Mexican American experiences in the 2oth century are extensive: exclusion or segregation for much of the first half of the twentieth century, as regional and local Anglo elites extended Jim Crow policies designed explicitly for Blacks to cover Mexicans, and a twentyfive-year period of change, 1950-1975, as these racial policies came under attack from various social movements demanding (among other things) firstclass citizenship. ${ }^{11}$ 


\section{THE CHICANO MOVEMENT}

The question of inclusion also suggests a different kind of politics, a "normal" or routinized institutional politics that stands in contrast to the "politics of protest" that took place roughly between 1965 and $1975 .{ }^{12}$ In the sixties, frustrated with the remaining segregationist limits and inspired by the Black civil rights movement, a general mobilization of the Mexican American community took place. The specific catalysts were the farm worker strikes in California and Texas in 1965-1966, which set off diverse organizing energies that quickly reverberated throughout the Southwest and later through the Midwest. These strikes ignited a broad civil rights mobilization among all classes of the Mexican American community - businessmen, professionals, college and high school students, factory workers, even the street youth. Unlike the assimilationist character of the earlier protests of the 1950 , these protests began to articulate a unifying nationalist vision that in its more militant guises was separatist. The activists took the pejorative lower-class label of Chicano and Chicana and transformed it into a powerful political identity.

Generally speaking, the Chicano movement scored few direct successeswinning a few rural county and town governments in Texas, fueling a landgrant reclamation movement in New Mexico, securing labor rights for farmworkers in California, and opening up universities throughout the region to Chicano youth. ${ }^{13}$ The Chicano movement, nonetheless, set the stage for considerable political reform, both nationally and locally, and made the moderate established organizations more acceptable. It left its imprint in the creation of new advocacy organizations - the Mexican American Legal Defense and Educational Fund (MALDEF), the Southwest Voter Registration and Education Project (SVREP), the National Council of La Raza (NCLR), for example - that would carry out and monitor the mandated dismantling of segregationist practices and institutions. Ironically, then, the Chicano movement reformed the "system"- not in the sweeping manner that movement rhetoric demanded-but sufficiently to move Chicanos off the streets and into the waiting rooms of the "house of power."

This pressure from below, of unprecedented intensity and geographic scope, laid the basis for a politics of inclusion. One can arguably peg 1975, the year the Voting Rights Act was extended to "language minorities," as a defining moment. In the same year the passage of the California Agricultural Labor Relations Act signaled the extension of labor rights to farmworkers, thus also bringing some closure to the events that had started the movement in 1965 . By the mid 1970s, the militant nationalist energy throughout the Southwest had dissipated, having been channeled on the one hand into cultural projects, community organizing, and nonpartisan political activities, and on the other 
into traditional partisan activities and business ventures. Generally speaking, the "Chicano generation" witnessed an uneven transition from segregation and powerlessness to integration and electoral influence, from the "politics of recognition" to the "politics of institutionalized power," as Christine Sierra describes it. ${ }^{14}$

Such basic change in American society led William J. Wilson to characterize the post-1975 period as one of the "declining significance of race." ${ }^{15}$ This was somewhat an overstatement, for race continues to carry considerable significance. Nonetheless, as Wilson noted, the political and social context in which the fact of race is debated and negotiated has changed dramatically. Race relations at the end of the twentieth century are markedly different from those at mid century or even in the seventies. Indeed, in the case of Mexican Americans, the uneasiness evident in the national commentaries suggests that the feared "browning" has already taken place.

\section{MEXICAN AMERICANS IN THE LATE TWENTIETH CENTURY}

Numbering some fourteen million in 1990, the Mexican American population will grow to comprise near majorities throughout the Southwest, especially in the key states of Texas and California, within the next generation. Everyday features of Southwestern life-food, music, and art are among the most obvious - underscore the Mexican influence. Indeed, Time magazine declared in a special July 1988 issue that "Hispanic culture" had broken "out of the barrio." 16

On university campuses in the region, the controversy over multiculturalism, while far from over, suggests that "Anglo conformity," the longreigning cultural paradigm for the United States, is under siege as we enter the twenty-first century. In fact, the universities generally lag behind the elementary schools, where the reality of multicultural student bodies has influenced the curriculum for some time.

In the world of commerce, the consumer market of the Mexican American population has an estimated value of one hundred billion dollars and has gained the attention of major market promoters. Conservative projections estimate that by the year 2000 Mexican Americans will own 320,000 business firms with annual business revenues of twenty billion dollars. And while there may be disagreement over trade agreements between the United States and Mexico, no one disputes that Mexican Americans will become an increasingly important intermediary in such binational commerce. ${ }^{17}$

Nowhere is this influence more evident than in the political arena. Currently Mexican Americans play key political roles in all Southwestern states 
and in several urban areas outside the region, in stark contrast with the pattern of exclusion for much of the twentieth century. The growth in Mexican American political participation in the Southwest has been dramatic: between 1976 and 1988 the number of registered voters doubled to more than three million, while the number of Latino elected officials likewise doubled to more than three thousand. In the past two decades, the watershed elections of Henry Cisneros as mayor of San Antonio, of Federico Peña as mayor of Denver, and of Gloria Molina as county supervisor of Los Angeles County, as well as the gubernatorial elections of Jerry Apodaca and Toney Anaya in New Mexico, signified not just an exponential increase in political representation but a qualitatively different level of representation for the Mexican American community.

At the state level, the makeup of the 1996-1997 Texas legislature easily demonstrated the significance of Mexican American influence: of the 150 House members, nearly one-fifth belonged to the Mexican American caucus; of the 3I senators, almost one-fourth were caucus members. In California, in spite of an anti-Latino climate (or perhaps because of it), Mexican Americans in 1996 gained thirteen seats in the eighty-member state assembly, making Cruz Bustamante the first Latino speaker of the lower house. ${ }^{18}$

At the national level, the mostly Democratic Congressional Hispanic Caucus, numbering in the r 990 os about a dozen members, had become increasingly effective in using the mechanics of "power brokering" not only to block detrimental legislation but, more importantly, to secure beneficial legislation. Despite the staunch Democratic Party affiliation of most Mexican Americans, the national Republican party has tried to make inroads with appeals to "family values" and business development; the result has been a sporadic competition between the Republican and Democratic parties for the Mexican American vote. Former President George Bush's appointment of Lauro Cavazos as secretary of education and Manuel Lujan as secretary of the interior, a serious bid to enlist Mexican Americans to the Republican fold, signaled national recognition of the Mexican American presence. The Democratic Party response was seen in President Clinton's cabinet appointments of Henry Cisneros as secretary of housing and urban development and Federico Peña as secretary of transportation for his first term, and the appointments of Peña as secretary of energy and Congressman Bill Richardson of New Mexico as UN ambassador for his second. These appointments suggest that Latino representation at the highest national level may have become institutionalized in partisan politics. ${ }^{19}$

In short, the "browning of America" proclaimed in the end-of-the-century accounts of journalists and pundits ironically suggests some measure of political inclusion. The friendlier commentaries describe Mexican Americans as 
"patriotic" and "real Hispanic Americans" and "worthy" (or "expecting no special help") - attempting, apparently, to soften the realization of an increasing Mexican presence in U.S. society.

The following studies look at the same reality with a different lens. Hopefully, they may begin to moderate the tenor and language dominating the current national discussion. At the minimum, they should demonstrate that voices on the other side of the American racial-ethnic divide are carrying on a very different discussion.

\section{ORGANIZATION OF THE VOLUME}

The articles in this book are grouped into three sections: community studies, institutional studies, and general studies.

\section{Community Studies}

In this section are grouped three studies that deal with the politics of specific urban communities, namely, San Antonio, Chicago, and Los Angeles.

Rodolfo Rosales, in his study of San Antonio politics in the 1980s, observes a curious result of the shift from at-large to single-member districts. As expected, single-member districts resulted in more ethnic representation on the city council, but they also promoted individualistic or "personal agenda" politics in place of the previous practice of collective or "organizational agenda" politics (which had been necessary for successful at-large campaigns). Presenting Mayor Henry Cisneros and Councilman Bernardo Eureste as examples of personal-agenda politicians, Rosales describes how community political influence remains elusive. Because the Chicano community has not forged a broad-based organizational agenda, the political field has once again been left to organized business interests.

Teresa Córdova's contribution takes us beyond the Southwest to the complex ethnic politics of Chicago during the mid eighties, a time when the old Daley political machine appeared to be unraveling. Córdova describes the rise of a progressive Black-Latino coalition with Harold Washington's mayoral victory in 1983 . This coalition was unable to consolidate its power, however, until the special aldermanic elections in 1986 , when four pro-Washington candidates - two Blacks, one Mexican American, one Puerto Rican - were elected. Shortly after the sudden death of Washington the following year, the coalition broke apart over the question of a successor. In 1989 , with support from some former coalition members (including future Congressman Luis Gutiérrez), Richard M. Daley, son of the former machine mayor, was elected mayor of Chicago. Thus did the Daley Machine become resurrected, though with a decidedly increased Black-Latino presence. 
The third contribution to this collection is Mary Pardo's study of the largest protest to emerge from East Los Angeles in the eighties. A grassroots protest movement, led by the church-based Mothers of East Los Angeles (MELA), was catalyzed by a State of California decision to locate a new prison in East Los Angeles. Pardo focuses on the developing political consciousness of the generally middle-aged, low-income women of MELA. Through their involvement they transformed their identities, especially of "motherhood," into a basis for militant opposition to projects that adversely affect the quality of life in their community. Pardo's study is a provocative account of the politicization of hundreds of working-class Mexican American women.

\section{Institutional Studies}

This section includes four studies that focus on the politics and policies of government agencies.

At the state level, we have Margarita Decierdo's assessment of California's Agricultural Labor Relations Board (ALRB) from 1975 through 1990, which touches on the unexpected consequences of a perceived victory. At the time of its creation in 1975, the ALRB was seen as the culmination of a ten-year struggle by the United Farm Workers, led by César Chávez, to secure union recognition and wage contracts with intransigent growers. From the outset, however, the new state agency faced serious obstacles in implementing the legal mediating framework intended to resolve the labor conflict. Indeed, the conflict itself was "imported" into the agency, with staff dividing itself into pro-grower, pro-farmworker, and neutral factions. The election of Republican Governor Deukmejian and subsequent pro-grower control of the ALRB led to a general purging of "pro-farmworker" staff. Thus the ALRB in the eighties, Decierdo concludes, ends up, ironically, being used as a mechanism to control farmworker union activities.

Phillip Gonzales grounds his analysis of university politics in a contentious dispute over affirmative action policy at the University of New Mexico in the mid 1980s. The determination of two influential Hispanic regents (one of them an ex-governor of the state) to pursue affirmative action alienated the university president and a large fraction of the Anglo faculty, who essentially countered by labeling the regents as ethnic politicians concerned with patronage. The ensuing public outcry against the regents' "meddling" led to the passage of a constitutional admendment adding two new seats to the Board of Regents, a move to undermine the Hispanic majority. Gonzales argues that this case illustrates the limits to ethnic advocacy as one moves up the institutional ladder, where "universalistic" goals are expected.

At the national level, Christine Sierra reviews a ten-year period (1976I986) of Chicano efforts to influence immigration reform to understand how 
the Congressional Hispanic Caucus and a Latino lobby in Washington engage in the politics of compromise, often at the expense of the Chicano community. The Caucus and the advocacy lobby proved successful in blocking the SimpsonMazzoli bill until the coalition fell apart over the question of legislative strategy. Some members of Congress and advocacy organizations felt that they needed to shed their obstructionist role and engage in "realistic politics" if they were to save the amnesty program. Sierra notes that while Chicano politicians and activists have demonstrated their ability to influence national policy making, they are now subject to pressure to moderate their demands and be pragmatic.

In similar fashion, Antonio González outlines the Chicano advocacy organizations' unprecedented consensus in the late eighties in opposing U.S. Central American policy, especially regarding the support of the Nicaraguan "contras." This coordinated opposition, led in particular by Willie Velásquez and the Southwest Voter Registration Education Project (SVREP), pressured the Congressional Hispanic Caucus to work to reverse Reagan administration policy, with success finally coming in 1988 . For González, this suggests not only a qualitative advance for Chicano politics but also a historic possibility of moderating the Monroe Doctrine that has justified U.S. hegemony in the Western Hemisphere.

\section{General Studies}

As noted earlier, an underlying theme that unifies these various studies is a concern with understanding what happened after the movement. Two contributions provide explicit overviews of the transition from movement politics to institutionalized politics, but each does it in a distinctive way.

Eric Xavier begins his intriguing study of El Teatro Campesino and its founder, Luis Valdez, in the mid sixties and takes us through the late eighties. Xavier explores the relationship between the politics and culture of the Chicano movement by reviewing the evolution of El Teatro Campesino, from farmworker theater performed on flatbed trucks to the "American plays" staged and filmed in Los Angeles. Xavier interprets the change in specific dramatic styles according to the changing fortunes of the Chicano movement. Xavier thus provides us a case study of how one Chicano cultural form has become "integrated" into American society, with theatrical and movie success as the evidence. It is a curious integration, however, for Valdez's contemporary efforts to write "American plays" for a broad audience have been seen in Hollywood primarily as an opening into the Hispanic market.

From another vantage point, Martín Sánchez Jankowski employs a unique data set - a longitudinal survey of youth in San Antonio, Albuquerque, and Los Angeles - to find out what happened to the nationalists he first inter- 
viewed in 1976 . Reinterviewing them in 1986, Sánchez Jankowski discovers that the "cultural nationalists" of the mid seventies have abandoned their position, whereas the "political nationalists" remain as committed as before. In this candid analysis of youth who have gone different political ways, Sánchez Jankowski notes that lower-class nationalists of the seventies generally remain the most radical, whereas many middle-class nationalists have turned to Republican party politics. Sánchez Jankowksi concludes that nationalism can reassert itself if inequality between Chicanos and Anglos worsens.

The volume concludes with my speculative study of the possible futures for Chicano-Anglo relations in the twenty-first century. The "politics of inclusion," I argue, basically reflects a certain understanding or convergence of interests between the prominent class groups of the Chicano and Anglo communities; specifically, the Chicano middle class, which wants political entry and opportunities, and the Anglo business elite, which wants support for its pro-development plans, have accommodated one another. Against this setting, I explore the implications of two much discussed projections: that the United States has already begun an economic decline within the world system and that ethnic demographic growth (or "browning") portends potential class polarization along ethnic lines. In summary, I argue that the convergence of these two projections poses serious challenges to the pro-development accommodation that makes for political inclusion.

\section{ON THE POLITICS OF INCLUSION}

What general points about political inclusion can be teased out from these wide-ranging studies? Three basic points appear to stand out.

The first is that inclusion, although referring to involvement in institutionalized problem-solving politics, is accompanied if not maintained by a politics of protest. All the community and institutional studies in this volume mention such mobilization. Protest politics catalyzed or underscored the various campaigns for voting rights (Rosales \& Córdova), quality of life (Pardo), labor rights (Decierdo), affirmative action (Gonzales), immigration policy (Sierra), Central American policy (González), and cultural expression (Xavier). Put another way, political inclusion signifies the assertion of community autonomy or influence in the policy-making process. The degree or extent of inclusion is the result of negotiation and, sometimes, of conflict.

A second general point, closely related to the first, deals with the distinct perspective - that "un-American agenda" most feared by conservative commentators - that Mexican Americans are introducing in American public policy. Inclusion signifies access and participation in policy- and decisionmaking agencies. Such participation necessarily entails the advocacy of a 
definite position on such questions as affirmative action, labor relations, bilingual education, immigration, foreign policy toward Latin America, multiculturalism, and so on. Most of the studies in this volume describe an unprecedented political situation that promised a "historic" introduction of a Chicano perspective. A critical ingredient was the development of an organizational infrastructure that could at times effectively express such a perspective.

This leads to a related third point about pragmatic politics: that this distinct ethnic perspective is moderated, compromised, or contained by participation in institutionalized politics. Indeed, the institutional limits that moderate or contain ethnic issues comprise the core of most of the studies; it is the most developed theme in the volume. These various studies demonstrate rather evident advances in access and representation within institutionalized politics, but these advances all prove to be fleeting or ambiguous. In San Antonio single-member districts end up encouraging individualistic or personal agendas rather than community-wide organizational ones. In Chicago the insurgent Washington mayoralty turns out to be a temporary lapse from Daley machine rule. In California, the much heralded Agricultural Labor Relations Board becomes transformed into a regulating agency of farmworker labor activity. In New Mexico the Hispanic regents of the flagship university are basically censured for their "ethnic politics." At the national level, the Simpson-Mazzolli immigration bill finally passes with the compromised support of the Congressional Hispanic Caucus, while the U.S. policy of supporting the Nicaraguan "contras," although finally overturned, reveals sharp differences within the Hispanic Caucus.

What these studies suggest, then, is that participation in institutionalized politics, while providing routinized access to decision making, at the same time sets limits on political behavior, promotes compromise at the possible expense of the "community," and may even undermine community organizational effectiveness. Such are the contradictions of inclusion.

\section{A FINAL WORD}

A word might be said about the organization of this volume. There was no conference or shared intellectual discussion to pull together ideas, smooth over differences, or reconcile disagreements; all papers were written independently of each other, not in concert with some overall design. The various studies employ very different approaches: demographic analysis, survey analysis, participant observation, interviews, life histories, and straightforward library research. Evident also are differences in ethnic identification preferred by the authors-Chicano, Mexican American, Mexican, Hispano, Latino; these were left as the author chose. 
There is no claim, of course, that this volume offers a thorough consideration of contemporary Chicano politics and society. Beyond Pardo's insightful discussion of the changing consciousness and identity of women activists, there is no treatment of gender or gendered politics. There is no theory of the "state," although Decierdo's provocative argument - that the state does not stand above the fray but reflects the class conflict occurring around it - points the way for further analysis. There is no sustained comparison with African Americans, although Córdova's description of Chicago politics is suggestive. Nor are all the compelling issues that point to the limits, unevenness, and uncertainties of inclusion - poverty and crime, school finance and school dropout rates, language policy and multiculturalism, foreign policy with a restive Mexico, for example-discussed in this volume. Nonetheless, these studies take an important first step. Taken together as a whole, they provide a panoramic view of post-movement politics and suggest directions for more research.

\section{NOTES}

r. Todd Gitlin, "Racial Obsession Taking a Toll," Austin American-Statesman, December I2, 1995; special issue on "California Fault Lines," Nation, Sept. 18, 1995; Mike Davis, "In L.A., Burning All Illusions," Nation, June I, I992, pp. 743-746; W. E. B. Du Bois, "To the Nations of the World," address to the Pan-African Conference, London, 1900.

2. "What Will the U.S. Be Like When Whites Are No Longer the Majority?" Time, April 9, 1990.

3. Lawrence E. Harrison, "America and Its Immigrants," National Interest (Summer, 1992), p. 45 .

4. William Langewiesche, "The Border," Atlantic Monthly, May 1992, p.65; David M. Kennedy, "Can We Still Afford to Be a Nation of Immigrants?" Atlantic Monthly, November 1996, pp. 52-68.

5. Georgie Anne Geyer, "Poll Shows Gulf Between Hispanics, Their 'Spokesmen,'” El Paso Times, Dec. 27, 1992; also "States Conduct Own Foreign Policy," Houston Post, Nov. 10, I983.

6. Peter Skerry, "Borders and Quotas: Immigration and the Affirmative Action State," Public Interest no. 96 (Summer 1989), pp. 86-102. For a full elaboration, see Skerry, Mexican Americans: The Ambivalent Minority (New York: Free Press, 1993).

7. William H. Frey and Jonathan Tilove, "Immigrants In, Native Whites Out," New York Times Magazine, August 20, 1995, pp. 44-45.

8. Jack Miles, "Blacks versus Browns: The Struggle for the Bottom Rung," Atlantic Monthly, October 1992, pp. 52-55, 68 .

9. Quoted in Paul S. Taylor, An American-Mexican Frontier: Nueces County, Texas (New York: Russell \& Russell, 1971), p. 232.

ro. See David R. Roediger, The Wages of Whiteness: Race and the Making of the American Working Class (New York: Verso, I99I); Reginald Horsman, Race and Manifest Destiny: The Origins of American Racial Anglo-Saxonism (Cambridge: Harvard University Press, 1981); Ronald T. Takaki, Iron Cages: Race and Culture in Nineteenth-Century America (New York: Alfred A. Knopf, 1979); Tomas Almaguer, Racial Fault Lines: The Historical Origins of White Supremacy in California (Berkeley: University of California Press, 1994). 
II. See Manning Marable, Race, Reform, and Rebellion: The Second Reconstruction in Black America, 1945-1990, rev. 2nd ed. (Jackson: University Press of Mississippi, 1991).

12. Protest activity, of course, antedated the sixties. There had occurred an earlier veteraninspired civil rights movement in the late 1940 s and early 1950s. This was the height of the "Mexican American Generation," a political generation that emphasized its American identity and progress toward assimilation. See Mario T. García, Mexican Americans: Leadership, Ideology, and Identity, 1930-1960 (New Haven: Yale University Press, 1989).

13. See David Montejano, Anglos and Mexicans in the Making of Texas, 1836-1986 (Austin: University of Texas, 1987 ).

14. Such recent entry into institutionalized politics signifies an ongoing learning experience. When the Congressional Hispanic Caucus proved successful in pushing for passage of the Voting Rights Language Assistance Act in August 1992, over the objections of Republicans and "Englishfirst" advocacy groups, the event was hailed as the first time that Hispanic leaders had played the Washington influence game "as insiders" to score major legislation. See "Breaking the Beltway Barrier: Can Lobbyists Win the War for Washington Clout?" Hispanic Business, April 1993, pp. 16-22.

15. William J. Wilson, The Declining Significance of Race: Blacks and Changing American Institutions (Chicago: University of Chicago Press, 1978).

16. Bureau of the Census, The Hispanic Population in the United States: March 1991, Current Population Reports, Series P-20, No. 455. Washington, D.C.: U.S. GPO, r991; special issue of Time, "Magnifico! Hispanic Culture Breaks Out of the Barrio," July I I, 1988.

I 7. See "The Hispanic Market: A Tremendous \$200-Billion Marketing Opportunity For All!," Telemarketing, November 1992; "30 Million by the year 2000: Annual Hispanic Market Issue," Hispanic Business, December 199r. For different views on NAFTA, see "Opening the Door to Mexico's Riches," Hispanic Business, January 1993, and Southwest Voter Research Institute, "The Impact of the North American Free Trade Agreement on Latino Workers in California and South Texas," Latin American Project Paper 2 (September 1992); "Talking Free Trade," Texas Observer, April 9, 1993, p.4.

I8. See, for example, Southwest Voter Registration Education Project, Latino Vote Reporter, vols. I-2 (1996 - 1997); "Polanco's Efforts Bear Fruit with Latino's Rise in Assembly," Los Angeles Times, December 26, 1996; "Latino Turnout a Breakthrough Election: Group's Heavy Balloting Could Signal a Historic Pivot Point for Political Relations in L.A.," Los Angeles Times, April ro, 1997.

I9. See "Breaking the Beltway Barrier: Can Lobbyists Win the War for Washington Clout?" Hispanic Business, April 1993; "What Clinton Will Do for Hispanics," Hispanic Magazine, Jan./ Feb. 1993; "Clinton Administration's Number of Hispanic Appointments Graded at C- and 'Unacceptable' by NHLA and NCLR Respectively," National Hispanic Reporter, May 1993; "Hispanics Organizing as Republican Entity," Austin American-Statesman, July I, 1995. 